Research Article

\title{
Effectiveness of Water Management towards Soil Moisture Preservation on Soybeans
}

\author{
Aminah Aminah $\mathbb{D}^{1}{ }^{1}$ Abdullah Abdullah, ${ }^{1}$ Nuraeni Nuraeni, ${ }^{1}$ Marliana S. Palad, ${ }^{2}$ \\ and Ida Rosada ${ }^{1}$ \\ ${ }^{1}$ Department of Agronomy, Faculty of Agriculture, Universitas Muslim Indonesia, Makassar, South Sulawesi 90231, Indonesia \\ ${ }^{2}$ Faculty of Agriculture Technology, Universitas Cokroaminoto, Makassar, South Sulawesi 90245, Indonesia
}

Correspondence should be addressed to Aminah Aminah; aminahmuchdar486@gmail.com

Received 11 January 2020; Accepted 27 February 2020; Published 20 May 2020

Academic Editor: Maria Serrano

Copyright (c) 2020 Aminah Aminah et al. This is an open access article distributed under the Creative Commons Attribution License, which permits unrestricted use, distribution, and reproduction in any medium, provided the original work is properly cited.

\begin{abstract}
In this study, factorial randomized experiments were conducted in a controlled greenhouse environment to investigate an efficient and effective component of water management technology in increasing soybean yield. The soybeans were planted in polybags with $6 \mathrm{~kg}$ of Alfisol soil media and fertilizer. The bags were perforated with 16 holes at approximately 1 to $2 \mathrm{~cm}$ from the base and put into a water container. The container was immersed in water levels of $5 \mathrm{~cm}$ and $10 \mathrm{~cm}$. The application of these immersions was carried out in four stages: 0 to 15 days after planting (DAP), 15 to $30 \mathrm{DAP}, 30$ to $45 \mathrm{DAP}$, and continued until harvest. Observations of growth were carried out on the greenness of leaves, plant height, leaf area, root length, and dry weight of plants, and soil water content was checked every two weeks. The yield measured after harvest consisted of the number of pods, the number of seeds/plants, weight of 100 seeds, and weight of seeds per plants. The water level had a significant effect on plant height, dry weight, leaf greenness, number of pods, and number of seeds/plants. The immersion stage has significant effects on plant height, harvest age, dry weight, leaf greenness, number of pods, and number of seeds/plants. Continuous immersion in a water level of $5 \mathrm{~cm}$ has shown the best yield on number of pods (20.81) and number of seeds per plant (162.94). This treatment increased seed yield (seed weight) approximately by $19.23 \%$ compared to the field capacity.
\end{abstract}

\section{Introduction}

The economic growth of developing countries such as Indonesia has changed the community consumption pattern towards a more diverse food pattern and balanced nutritional content. This implies that the food produced needs to adjust market demands so that it can provide a variety of foodstuffs to meet the consumption of the population. Regarding changes in consumption patterns, vegetable protein needs will continue to increase along with population growth, urbanization, and increased income.

Soybean as a food that is very popular in Indonesia ranks third after rice and corn because it has a fairly high protein content. Because domestic production is unable to keep up with national needs, it must be consumed by importing [1]. Optimal growth and yield of crops can be achieved if water, as the most important factor in plant growth, is available in sufficient quantities according to crop needs.

In areas with insufficient water availability, water management efforts are needed. Important factors that underlie water management are the characteristics of plants for water needs, the amount of water supplied, irrigation methods, and soil characteristics in storing water. These factors are also influenced by local agroecological conditions such as climate, soil type, and irrigation water availability. Lack of information on crop water needs in tropical conditions is one of the causes of inefficient water use and inadequate irrigation management [2].

Another thing that must be taken into account in water management is climate change because it can have a negative impact on soybean cultivation. One of the main impacts of climate change is reducing the availability of water for 
irrigation purposes in all regions [3]. Innovative irrigation practices can improve water efficiency, provide economic benefits, and also reduce environmental burden. In some cases, the necessary knowledge has been provided by extending services, helping farmers to adapt and implement feasible solutions, so as to obtain more benefits from irrigation technology [4]. Agricultural water management technologies such as Limpopo have been widely applied, to close yield gaps, improve food security, and reduce poverty. Enough evidence has been found that this technology can provide large benefits by increasing yields and water productivity with reduced environmental impact. Farmer responses to addressing projected impacts include autonomous and planned adaptation strategies, such as modifying planting dates to maximize crop growth calendar and available soil moisture, increasing the use of water conservation measures on agricultural land, and leveling the soil to improve water efficiency in rice schemes depending on surface irrigation [5]. Previous studies conducted using water table controls set at $0.50 \mathrm{~m}$ and $0.75 \mathrm{~m}$ from the soil surface showed an increase in yields of $8.5 \%$ and $12.9 \%$ [6]. Another study was carried out using Sachiyutaka cultivars with water levels of $20 \mathrm{~cm}$ and $35 \mathrm{~cm}$ which showed that growth and yields can be increased, especially at the end of planting. However, groundwater levels should not be maintained at $20 \mathrm{~cm}$ for soybeans that are planted late [7]. Research on the prediction of planting time in water management using the CropSyst model showed that there is a relationship between the data obtained in the field and the CropSyst model simulation shown by the Efficiency Index value of 0.679 [8]. Considering the different water requirements for different soybean cultivars, a study was conducted to test the level of water requirements below $20 \mathrm{~cm}$. Therefore, one of the solutions offered in this research is to find an appropriate water management system to meet the water needs of soybean plants to support food safety. The purpose of this study is to obtain an efficient and effective component of water management technology in maintaining soil to support the security of food.

\section{Materials and Methods}

This study was carried outt in a greenhouse, adopting an experimental approach using a two-factor randomized block design. The soybeans were immersed with water levels of $5 \mathrm{~cm}$ and $10 \mathrm{~cm}$. The application of these immersions was performed in four stages: 0 to $15 \mathrm{DAP}, 15$ to $30 \mathrm{DAP}, 30$ to $45 \mathrm{DAP}$, and continued until harvest. The treatments were replicated three times.

This treatment used Anjasmoro variety of soybeans. Soybeans were planted in polybags with $6 \mathrm{~kg}$ of Alfisol soil media. The bags were perforated with 16 holes at approximately 1 to $2 \mathrm{~cm}$ from the base. The bags were put into a box containing water according to the treatment. In accordance with the planting time, the basic fertilizers were given at a dose of $50 \mathrm{~kg}$ of nitrogen (46\%), $75 \mathrm{~kg}$ of phosphorous (36\%), and $75 \mathrm{~kg}$ of potassium (60\%) per hectare.

Observations of growth were carried out on the greenness of leaves, plant height, leaf area, root length, and dry weight of plants, and soil water content was checked every two weeks. The yield was measured after harvest which consisted of the number of pods, the number of seeds/plant, weight of 100 seeds, and weight of seeds/plants.

\section{Results and Discussion}

The results of observations on soil moisture content before and after immersion are presented in Table 1. Before the immersion treatment, all soil types had a moisture content around field capacity, which ranged from $37.18 \%$ to $39.89 \%$. Continuous immersion until harvest consumed the highest water volume in both treatments at water levels of $5 \mathrm{~cm}$ $(20740 \mathrm{ml})$ and $10 \mathrm{~cm}(20950 \mathrm{ml})$. Likewise, soaking within 15 days required water above the field capacity. In general, treatment using a water level of $10 \mathrm{~cm}$ required more water volume than that of $5 \mathrm{~cm}$; thus, the average of soil moisture content was also higher after immersion in this treatment (Table 1).

The results of observations on plant height, harvest age, leaf area, root length, and dry weight plant are presented in Table 2. Treatment of water level had a significant effect $(p<0.05)$ on plant height and dry weight, while the immersion stage had a significant effect $(p<0.05)$ on plant height, harvest age, and dry weight. Treatment with a water level of $5 \mathrm{~cm}$ in average resulted in greater plant height than that of $10 \mathrm{~cm}$. With the treatment of $5 \mathrm{~cm}$ of water level, the greatest plant height was found in the stage of continuous immersion until harvest $(63.54 \mathrm{~cm})$ followed by immersion in 30 to 45 DAP $(54.33 \mathrm{~cm})$. Meanwhile, dry weight of the plant was also greatest in the stage of continuous immersion until harvest (47.03 gr), followed by immersion in 0 to 15 DAP (34.15 gr). The immersion stage has affected the harvest age. Continuous immersion until harvest with the water level of $10 \mathrm{~cm}$ had the fastest harvest time (76.44 days), while that of 0 to 15 DAP had the longest harvest time ( 89.18 days) (Table 2).

Treatment with water level had a significant effect $(p<0.05)$ on leaf greenness, number of pods, number of seeds per plant, and weight of seeds per plant. Immersion stage had a significant effect $(p<0.05)$ on leaf greenness, number of pods, and number of seeds per plant. Treatment with a water level of $5 \mathrm{~cm}$ in average resulted in higher leaf greenness, number of pods, number of seeds per plant, and weight of seeds per plant than that of $10 \mathrm{~cm}$. Water level and implementation of immersion determined the greenness of the leaves which is an indicator of the chlorophyll content of leaves. With the treatment of $5 \mathrm{~cm}$ water level, the highest leaf greenness was found in immersion in 0-15 DAP (37.19), followed by that of 30 to 45 DAP (36.45). The number of pods was highest in continuous immersion until harvest (20.81), followed by that of 30 to 45 DAP (18.74). The number of seeds per plant was highest in the stage of continuous immersion until harvest (162.94), followed by that of 30 to 45 DAP (119.51). The weight of 100 seeds per was highest in the stage of 0 to $15 \mathrm{DAP}(10.58 \mathrm{~g})$, followed by that of 15 to $30(10.57 \mathrm{~g})$. The weight of seeds per plant was highest in the stage of continuous immersion until harvest (12.69), followed by that of 30 to 45 DAP (10.67) (Table 3). 
TABLE 1: Effect of water level and immersion time on the amount of water given to soil before and after immersion.

\begin{tabular}{|c|c|c|c|}
\hline Treatment & Amount of water $(\mathrm{ml})$ & Moisture content before soaking (\%) & Moisture content after soaking (\%) \\
\hline \multicolumn{4}{|l|}{ Water level $5 \mathrm{~cm}$} \\
\hline 0 to $15 \mathrm{DAP}$ & 16600 & 38.82 & 42.55 \\
\hline 15 to $30 \mathrm{DAP}$ & 16550 & 38.79 & 42.60 \\
\hline 30 to $45 \mathrm{DAP}$ & 16500 & 38.25 & 44.45 \\
\hline Constantly continue until harvest & 20740 & 39.89 & 46.44 \\
\hline \multicolumn{4}{|l|}{ Water level $10 \mathrm{~cm}$} \\
\hline 0 to $15 \mathrm{DAP}$ & 16840 & 38.60 & 43.10 \\
\hline 15 to $30 \mathrm{DAP}$ & 16540 & 37.30 & 44.58 \\
\hline 30 to $45 \mathrm{DAP}$ & 16600 & 37.18 & 45.40 \\
\hline Constantly continue until harvest & 20950 & 38.63 & 46.80 \\
\hline Field capacity & 12130 & $38.80^{*}$ & \\
\hline
\end{tabular}

*Soil moisture content is maintained in field capacity.

TABLE 2: Effect of water level and immersion time on plant height, harvest age, leaf area, root length, and dry weight of biomass at harvest.

\begin{tabular}{|c|c|c|c|c|c|}
\hline Treatment & Plant height $(\mathrm{cm})$ & Harvest age (days) & Leaf area $\left(\mathrm{cm}^{2} /\right.$ plant $)$ & Root length $(\mathrm{cm})$ & Dry weight $(\mathrm{g})$ \\
\hline \multicolumn{6}{|l|}{ Water level $5 \mathrm{~cm}$} \\
\hline 0 to $15 \mathrm{DAP}$ & $49.30 \mathrm{~cd}$ & $84.56 b$ & $520.66 a$ & $44.33 \mathrm{a}$ & $34.15 b$ \\
\hline 15 to $30 \mathrm{DAP}$ & $49.54 \mathrm{~cd}$ & $84.72 b$ & $525.96 a$ & $43.84 \mathrm{a}$ & $29.89 \mathrm{bcd}$ \\
\hline 30 to $45 \mathrm{DAP}$ & $54.33 b$ & $85.84 \mathrm{c}$ & $479.23 \mathrm{a}$ & $42.66 \mathrm{a}$ & $30.97 \mathrm{bcd}$ \\
\hline Constantly continue until harvest & $63.54 \mathrm{a}$ & $86.07 \mathrm{c}$ & $485.34 \mathrm{a}$ & $43.69 \mathrm{a}$ & $47.03 \mathrm{a}$ \\
\hline \multicolumn{6}{|l|}{ Water level $10 \mathrm{~cm}$} \\
\hline 0 to $15 \mathrm{DAP}$ & $50.21 \mathrm{c}$ & $89.18 c$ & $487.47 \mathrm{a}$ & $41.91 \mathrm{a}$ & $29.52 \mathrm{~cd}$ \\
\hline 15 to $30 \mathrm{DAP}$ & $47.57 \mathrm{~d}$ & $89.07 \mathrm{e}$ & $482.71 \mathrm{a}$ & $43.09 \mathrm{a}$ & $24.55 \mathrm{e}$ \\
\hline 30 to $45 \mathrm{DAP}$ & $48.78 \mathrm{~cd}$ & $86.56 \mathrm{~d}$ & $465.47 \mathrm{a}$ & $41.67 \mathrm{a}$ & $27.22 \mathrm{de}$ \\
\hline Constantly continue until harvest & $61.14 \mathrm{a}$ & $76.44 a$ & $521.51 \mathrm{a}$ & $42.93 a$ & $32.60 \mathrm{bc}$ \\
\hline Field capacity & $45.02 \mathrm{e}$ & $84.77 \mathrm{~b}$ & $469.55 \mathrm{a}$ & $42.56 \mathrm{a}$ & $28.03 \mathrm{de}$ \\
\hline HSD $5 \%$ & 2.42 & 0.32 & $65.55^{\mathrm{ns}}$ & $3.21^{\mathrm{ns}}$ & 4.34 \\
\hline
\end{tabular}

HSD: honestly significant difference; ns = not significant. The numbers followed by different letters indicate significance.

TABLE 3: Effect of water level and immersion time on leaf greenness, number of seeds/crops, the weight of 100 seeds, and the weight of seeds/ crop.

\begin{tabular}{|c|c|c|c|c|c|}
\hline Treatment & $\begin{array}{c}\text { Leaf } \\
\text { greenness }\end{array}$ & $\begin{array}{l}\text { Number of } \\
\text { pods }\end{array}$ & Number of seeds/plants & Weight of 100 seeds (g) & Weight of seeds/plants (g) \\
\hline \multicolumn{6}{|l|}{ Water level $5 \mathrm{~cm}$} \\
\hline 0 to $15 \mathrm{DAP}$ & $37.19 \mathrm{a}$ & $12.78 \mathrm{c}$ & $95.77 \mathrm{~cd}$ & $10.58 \mathrm{a}$ & $9.93 \mathrm{bc}$ \\
\hline 15 to $30 \mathrm{DAP}$ & $34.67 \mathrm{~b}$ & $14.01 \mathrm{c}$ & $104.64 c$ & $10.57 \mathrm{a}$ & $9.67 \mathrm{~cd}$ \\
\hline 30 to $45 \mathrm{DAP}$ & $36.45 \mathrm{a}$ & $18.74 b$ & $119.51 b$ & $9.04 \mathrm{c}$ & $10.67 \mathrm{~b}$ \\
\hline Constantly continue until harvest & $36.19 \mathrm{a}$ & $20.81 \mathrm{a}$ & $162.94 \mathrm{a}$ & $9.63 \mathrm{~b}$ & $12.69 \mathrm{a}$ \\
\hline \multicolumn{6}{|l|}{ Water level $10 \mathrm{~cm}$} \\
\hline 0 to $15 \mathrm{DAP}$ & $31.23 c$ & $13.77 \mathrm{c}$ & $89.47 \mathrm{def}$ & $9.77 b$ & $9.02 \mathrm{~d}$ \\
\hline 15 to $30 \mathrm{DAP}$ & $26.15 d$ & $13.44 \mathrm{c}$ & $75.42 \mathrm{f}$ & $8.98 \mathrm{c}$ & $7.76 \mathrm{e}$ \\
\hline 30 to $45 \mathrm{DAP}$ & $36.21 \mathrm{a}$ & $13.52 \mathrm{c}$ & $80.68 \mathrm{ef}$ & $9.08 \mathrm{c}$ & $7.87 \mathrm{e}$ \\
\hline Constantly continue until harvest & $30.34 \mathrm{c}$ & $14.01 \mathrm{c}$ & $93.79 \mathrm{cde}$ & $9.04 \mathrm{c}$ & $7.09 \mathrm{e}$ \\
\hline Field capacity & $36.83 a$ & $14.34 \mathrm{c}$ & $101.68 \mathrm{~cd}$ & $9.91 b$ & $10.25 b c$ \\
\hline HSD 5\% & 1.16 & 1.74 & 14.61 & 0.44 & 0.89 \\
\hline
\end{tabular}

HSD $=$ honestly significant difference. The numbers followed by different letters indicate significance.

The treatment of continuous immersion in a water level of $5 \mathrm{~cm}$ increased seed yield (seed weight) approximately by $19.23 \%$ compared to field capacity.

Water level and implementation of immersion determined the greenness of the leaves which is an indicator of chlorophyll content of leaves. The greenness of leaves correlates with the chlorophyll content in leaves because dark leaves consist of more chlorophyll. Chlorophyll control supports high photosynthesis ability, and it can also be a sensitive tool to increase large variations of genotype [9]. Chlorophyll is a pigment that has a function in plant photosynthesis. In photosynthesis, plant chlorophyll is a complex molecule that connects solar energy, which involves the process of transferring energy and electrons [10]. Chlorophyll levels were affected by soil conditions that are high in nitrogen. In deficit irrigation conditions, this can also be fulfilled by the application of organic compost and soil mulch [11]. Supplying new compost made from sugarcane 
bagasse and animal blood used for deficit drip irrigation can be a practical solution to avoid the adverse effects of irrigation in sugar beets [12].

Immersion in a water level of $5 \mathrm{~cm}$ generally resulted in higher production than that of $10 \mathrm{~cm}$. This is probably due to plant height, leaf chlorophyll content, leaf area width, and root length, which led to better seed production. The application of continuous water immersion has a higher production rate, possibly due to the fulfillment of water requirements for all stages of soybean growth. In a study conducted with a lysimeter for field conditions that were defined as irrigation, it was observed that constant water depths were higher than the irrigation treatment [13]. Conversely, immersion in a water level of $10 \mathrm{~cm}$ in the late stage led the plant to grow shorter. In this condition, the plant is considered to have an acclimatization stage in the condition of the soil environment which changes the groundwater content from field capacity to above the field capacity, which causes a decrease in growth variation in the plants that are observed. This condition shows symptoms of chlorosis which is a characteristic of nitrogen deficiency. This phenomenon may due to water saturation; the fixating ability is reduced because many soybean roots were rotten and dead, so the surface power of nutrient absorption was also reduced and, eventually, the leaves of soybean plants became bright green [14].

Biomass accumulation produced by the plant treated with a water level of $5 \mathrm{~cm}$ was greater that that of $10 \mathrm{~cm}$. Continuous immersion in a water level of $5 \mathrm{~cm}$ increased seed yield by $19.23 \%$ compared to controls. This result was supported by the data that the number of pods and the number of seeds/plants increased by $31.1 \%$ and $37.59 \%$ above the field capacity. On the contrary, continuous immersion in a water level of $10 \mathrm{~cm}$ showed the lowest seed weight that fell to 7.09 grams. This situation conforms with prediction because soybean is very sensitive to high levels of water flooding.

Observations on the weight of 100 seeds showed that the $5 \mathrm{~cm}$ immersion treatment in 0-15 DAP and 15-30 DAP showed significant differences with the field capacity treatment where there was an increase in weight of 100 seeds by $5.8 \%$ compared to field capacity. This is probably caused by compensation from the low number of pods and the yield of seeds/plants in the treatment so that the photosynthate yield has flowed into the reduced seeds. Therefore, soybean plants that lack water during their growth have several seeds/ pod, and the number of pods and the weight of seeds/plant are lower but there is a higher weight of 100 seeds.

Irrigation techniques by continuous immersion in a water level of $5 \mathrm{~cm}$ seem to have the potential to increase soybean yield. From these results, it is suggested that the way of irrigation until the soil is saturated with water or above the field capacity is still quite safe for plant growth. In the field of technology, this system is referred as the wet soil culture or saturated soil culture by some researchers. The results of wet cultivation studies on soybeans in the field can increase the yield by about $70 \%$ compared to conventional irrigation [15].

Soil characteristics in the study sites showed that the soil quality was below standard. Land for soybean farming was characterized by low nitrogen content $(0.14 \%)$, but normal carbon and nitrogen ratio [14]. Other chemical properties
TABle 4: Chemical and physical characteristics of the soil in the study site.

\begin{tabular}{lc}
\hline Chemical and physical characteristics & Value \\
\hline Carbon (\%) & 2.01 \\
Nitrogen (\%) & 0.14 \\
Carbon/nitrogen ratio & 14 \\
Phosphor (ppm) & 19.6 \\
Calcium (mg/L) & 8.63 \\
Magnesium (mg/L) & 5.21 \\
Potassium (mg/L) & 0.25 \\
Natrium (mg/L) & 0.33 \\
Cation exchangeable capacity & 25.6 \\
Saturated base (\%) & 56 \\
Sand (\%) & 22 \\
Dust (\%) & 32 \\
Clay (\%) & 46 \\
\hline
\end{tabular}

were also found in low concentration, such as calcium $(8.63 \mathrm{mg} / \mathrm{L})$, magnesium $(5.21 \mathrm{mg} / \mathrm{L})$, and potassium $(0.25 \mathrm{mg} / \mathrm{L})$ (Table 4$)$.

This study suggested that water immersion at that time is an important factor that needs to be considered to improve the efficiency of water use and increase soybean seed yields, especially those grown in the dry land of Alfisol. Another study showed that chemical elements in soil such as potassium content affect the soybean yields. Application of 150 and $120 \mathrm{~kg} \mathrm{ha}^{-1}$ of potassium significantly increased seed yield. Higher levels of potassium content in a dry environment improved the water status of plants as well as the growth and yield of soybean under water pressure [16].

The availability of water during plant growth greatly determines the yield of soybeans. The need for water for soybeans during the process of plant growth ranges from 450 to $700 \mathrm{~mm} /$ season, depending on climate conditions and plant age. The amount needed is different in each phase of growth. Water consumption for soybean plants is highly dependent on climate, soil type, soil management, and duration of plant growth; thus, the water requirements for each agroecosystem area are different. Although soybeans are crops that do not need much water, during the early stages of growth, flowering, and filling in pods, the availability of water is very necessary. If you experience drought at the stage, the productivity of soybeans can decrease by 40-65\% [17]. Another study showed that in deficit irrigated plots, seed yield of soybean was increased by $1.15 \%$ to $7.5 \%$ during three years as compared to control plots. In the average climate situation with high soil water content at fully irrigated plots, grain yield of soybean was reduced [18].

Previous results found that soybeans given $150 \mathrm{~mm} /$ season of water stress (below normal requirements) showed a very significant difference with $300 \mathrm{~mm} /$ season of soybeans/season (normally required), which was a very real reduction in both the components of plant growth and the components of production [19].

\section{Conclusions}

This research concluded that continuous immersion in a water level of $5 \mathrm{~cm}$ has shown the best yield on number of 
pods (20.81) and number of seeds per plant (162.94). This treatment increased seed yield (seed weight) approximately by $19.23 \%$ compared to field capacity.

\section{Data Availability}

All data generated or analysed during this study are included in this article. The full data used to support the findings of this study are available from the corresponding author upon request.

\section{Conflicts of Interest}

The authors declare that there are no conflicts of interest regarding the publication of this paper.

\section{Acknowledgments}

The authors would like to thank the Ministry of Research Technology and Higher Education of Indonesia (Grant no. 0541.a/B.07/UMI/II/2019) for funding this research.

\section{References}

[1] W. S. D. Yamika and K. R. Ikawati, "Combination inorganic and organic fertilizer increased yield production of Soybean in rain-field Malang, Indonesia," American-eurasian Journal of Sustainable Agriculture, vol. 6, pp. 14-17, 2012.

[2] E. H. F. M. da Silva, A. O. Gonçalves, R. A. Pereira, I. M. Fattori Júnior, L. R. Sobenko, and F. R. Marin, "Soybean irrigation requirements and canopy-atmosphere coupling in Southern Brazil," Agricultural Water Management, vol. 218, pp. 1-7, 2019.

[3] A. Iglesias, L. Garrote, F. Flores, and M. Moneo, "Challenges to manage the risk of water scarcity and climate change in the mediterranean," Water Resources Management, vol. 21, no. 5, pp. 227-288, 2007.

[4] L. Levidow, D. Zaccaria, R. Maia, E. Vivas, M. Todorovic, and A. Scardigno, "Improving water-efficient irrigation: prospects and difficulties of innovative practicesficient irrigation: prospects and difficulties of innovative," Agricultural Water Management, vol. 146, pp. 84-94, 2014.

[5] A. Daccache, W. Sataya, and J. W. Knox, "Climate change impacts on rain-fed and irrigated rice yield in Malawi," International Journal of Agricultural Sustainability, vol. 13, no. 2, pp. 87-103, 2015.

[6] M. N. Mejia, C. A. Madramootoo, and R. S. Broughton, "Influence of water table management on corn and soybean yields," Agricultural Water Management, vol. 46, no. 1, pp. 73-89, 2000.

[7] N. Matsuo, M. Takahashi, H. Nakano et al., "Growth and yield responses of two soybean cultivars grown under controlled groundwater level in Southwestern Japan," Agronomy \& Crop Ecology, vol. 16, pp. 84-94, 2009.

[8] A. Aminah, A. Ala, Y. Musa, R. Padjung, and K. Kaimuddin, "Strategy of soybean management (Glycine max L.) to cope with extreme climate using CropSyst model," AGRIVITA Journal of Agricultural Science, vol. 39, no. 3, pp. 324-328, 2017.

[9] B. L. Ma, M. J. Morrison, and H. D. Voldeng, "Leaf greenness and photosynthetic rates in soybean," Crop Science, vol. 35, no. 5, pp. 1411-1414, 1995.
[10] L. Taiz and E. Zeiger, Plant Physiology, Sinauer Associates, Inc. Publishers, Sunderland, MA, USA, 3rd edition, 2002.

[11] T. A. A. El-Mageed, I. M. El-Samnoudi, A. E. A. M. Ibrahim, and A. R. A. El Tawwab, "Compost and mulching modulates morphological, physiological responses and water use efficiency in (Sorghum bicolor L. Moench) under low moisture regime," Agricultural Water Management, vol. 208, pp. 431439, 2018.

[12] T. A. A. El-Mageed, A. M. A. El-Sherif, S. A. Abd El-Mageed, and N. M. Abdou, "A novel compost alleviate drought stress for sugar beet production grown in Cd-contaminated saline soil," Agricultural Water Management, vol. 226, p. 105831, 2019.

[13] Y. F. Fidantemiz, X. Jia, A. L. Daigh et al., "Effect of water table depth on soybean water use, growth, and yield parameters," Water, vol. 11, pp. 1-12, 2019.

[14] R. J. Troedson, D. E. L. Byth, and G. L. Milson, "Saturated soil culture and innovation water management option for soybean in the tropics and subtropics," in Soybean in Tropical and Subtropical Cropping System. Proceedings of the Symposium at Tsukuba, S. Shanmugasundaram and E. W. Sulzberger, Eds., pp. 275-285, Springer, Berlin, Germany, 1983.

[15] A. Suryana, Menggenjot Produksi Kedelai Dengan Teknologi Diskusi Panel Dan Konfrensi Pers. Inovasi Teknologi Kedelai, Badan Litbang Pertanian Jakarta. 12 Pebruari 2008, Penebar Swadaya, Jakarta, Indonesia, 2007.

[16] T. A. A. El-Mageed, M. A. Ahmed, M. A. Mahmoud, and H. A. Mohamed, "Combined effect of deficit irrigation and potassium fertilizer on physiological response, plant water status and yield of soybean in calcareous soil," Archives of Agronomy and Soil Science, vol. 63, no. 6, pp. 827-840, 2017.

[17] T. Adisarwanto and R. Wudlanto, "Peningkatan hasil panen kedelai di lahan sawah kering-pasang Surut. Jakarta," Penebar Swadaya, vol. 33, pp. 1-3, 2007.

[18] M. Marković, M. Josipović, M. M. Ravlić, A. Josipović, and V. Zebec, "Deficit irrigation of soybean (Glycinemax. (L.) Merr.) based on monitoring of soil moisture, in sub-humid area of eastern Croatia," Romanian Agricultural Research, vol. 30, pp. 1-8, 2016.

[19] K. Aminah, S. Jusoff, S. Hadijah et al., "Increasing soybean (Glycine $\max \mathrm{L}$ ) drought resistance with osmolit sorbitol," Modern Applied Science, vol. 7, no. 9, 2013. 